Article

\title{
What Is Genealogy? Philosophy, Education, Motivations and Future Prospects
}

\author{
Bruce Durie
}

Honorary Fellow, University of Strathclyde, 16 Richmond St, Glasgow G1 1XQ, UK; bruce@durie.scot

Academic Editor: Philip Kretsedemas

Received: 9 November 2016; Accepted: 2 January 2017; Published: 10 January 2017

\begin{abstract}
This article is a first attempt to generate discussion and academic analysis of the modus operandi of genealogy and genealogists. Genealogy is on the verge of becoming a recognised profession and an academic discipline, with one or more qualification routes. This article summarises the author's philosophy, motivations and experiences in establishing educational/training courses and qualifications in a University context. Definitions of genealogy and related concepts are discussed, in the light of an epistemological analysis. Such philosophical considerations are rarely discussed among professional genealogists. It is hoped this article will be a stimulus to more enlightened debate of the epistemological and philosophical bases of family history-type genealogy. There is also a dearth of research into the motivations of amateur and professional genealogists, and almost no scholarly scrutiny of genealogy as an academic discipline. Nor can it be dismissed as "a branch of history"; genealogy and history are related but separate disciplines with overlapping skills-sets.
\end{abstract}

Keywords: genealogy; education; qualification; profession; University of Strathclyde; Durie; genealogical proof; genealogical standards

\section{Introduction}

Genealogy is on the cusp of becoming an all-qualified profession, and moving from an "amateur" (in the original sense of the word) pursuit to a "professional" activity, with one or more-often competing-routes to education, qualification, certification etc., and some resistance from a number of "certification" bodies which has generated a number of tensions, some of which are discussed below ${ }^{1}$. However, it is necessary to place this in context, with some definitions. These are not necessarily universally accepted, nor are they suggested as all-encompassing. But they are given so that reader will understand what the author intends to indicate by their use, and as a stimulus to further discussion and debate.

It is also hoped that opening up a debate on the philosophical underpinnings to family history-type genealogy will lead to more discussion of this, and stimulate motivational research.

\section{Definitions-What Is Genealogy?}

Genealogy is what genealogists do. That's a circular argument, of course, but it serves as a pragmatic starting-point for a discussion of the "tight" definition of genealogy. It purposely ignores, for the moment, wider definitions such as those of Bernard Williams ${ }^{2}$. This is at once: a process or research methodology; a term for the outcome of such research; and the overall expression for the

1 This aspect-levels of educational attainment vs. certifications and "short courses"—will be more fully addressed in an upcoming Special Issue of Genealogy.

2 A genealogy is a narrative that tries to explain a cultural phenomenon by describing a way in which it came about, or could have come about, or might be imagined to have come about-paraphrased from ([1], p. 20). 
pursuit, whether professional or amateur. Genealogy is the retrieval of vital and familial data from records of various types, and its ordering into meaningful relationship patterns. It involves, at least, the discovery and proof of vital data (names, dates, places of birth, marriage, death events), plus surrounding and contextual information-occupations, migration events, other socio-geographical data found in censuses, testamentary details and so on. It comprises, therefore, the basic data on which further socio-historical and narrative information is built. At the very least, it allows related individuals to be organized into a "tree" - either and both as a pedigree (starting with one index individual and working backwards in time to lineal ancestors), and/or a lineage (working forwards in time from an ancestor to descendants, and collateral lines).

As a methodology, genealogy depends on the existence or primary sources-official and other records of vital and other events such as court cases, deeds etc.-or where these do not exist, reliable substitutes.

Sadly, not all substitutes are reliable-compiled genealogies are notoriously untrustworthy, and in some cases purposely falsified to establish a case. Even supposedly definitive works of record (those of Burke and successors, for instance) may be fundamentally flawed in places, but tend to be taken at face value without further scrutiny or challenge.

Family History-this takes the basic data of genealogical investigations and includes the surrounding historical, economic, social, political and other contexts, to build a connected narrative. It seeks to describe and/or explain, for example: why one branch of a family migrated while another stayed put; the vagaries of social and economic status over time ("who got the land and the money?"); the circumstances surrounding marriages and children; and so forth.

Surname Research (e.g., a one-name study) concerns itself with the origins, meanings, transmission and continuity of single or linked family names and their variants.

Genetic Genealogy attempts to place individuals within family, ethnic and geographical groupings by analysis of DNA and its expression. This is true citizen-science, and the world of academic genetics; having initially dismissed it as a form of stamp-collecting or astrology, is only slowly catching up.

\section{Transdisciplinarity}

Genealogy (in the sense used above) is transdisciplinary. It combines the forensic skills of vital data research with considerations of the law, genetics and molecular biology, heraldry, social geography, and a knowledge of history. This last—-the necessity for detailed historical knowledge-has often led professional and academic historians to claim that genealogy is simply "a branch of history", but that is no more the case than, say, chemical engineering is a branch of mathematics, or that someone skilled in civil engineering could design an aircraft. Frankly, genealogy has suffered from academic neglect. There is as yet no Chair in genealogy in any UK university, and worldwide hardly any academics whose primary function is to research, teach, write and reflect on genealogy. It has not yet achieved the status of a discipline.

The very transdisciplinarity of Genealogical Studies (as it is called at the University of Strathclyde) is partly at the root of this. Historians do not necessarily understand (or care about) genetics; palaeographers typically have no interest in family histories; antiquarians rarely concern themselves with present-day lives; social scientists are skeptical and sometimes openly hostile to what they perceive as entrenched pseudo-feudal relationships and social structures.

Transdisciplinary theory [2] itself is a concept the vast majority of genealogists would not recognise, and there is hardly any philosophical reflection on the discipline within the profession. When Piaget first used the term in the early 1970s to indicate a unity of knowledge that goes beyond disciplines, and often involving specialized languages in differing fields of expertise, he could have been speaking about genealogy [3]. 


\section{Motivations of Genealogists ${ }^{3}$}

The reasons why genealogists explore family histories and their contexts are as varied as the individuals concerned. However, those who pursue "amateur" (usually unpaid) research on their own family and its branches, typically report a search for identity, a desire to know something of the lives of their ancestors and their place in wider society. A few regard it as a form of stamp-collecting ("I have 1500 people on my family tree!"). Some are seeking answers to long-standing problems, often related to the inheritance of land, money and/or titles, but increasingly patterns of causes of death ("medical genealogy") or deep ethnic ancestries ("where did we come from?")

Professional genealogists have typically started out as amateurs researching their own lines, but have turned their skills into a paid-for service, whether full-time or part-time.

Genealogy is, in a sense, as old as recorded history. Many cultures had an oral tradition of reciting pedigrees, and important figures would have theirs recorded. The Old Testament is full of "begatting". The accuracy of such records is, of course, doubtful, as is their intent. The ancient Pictish and Irish King Lists were initiated, or earlier versions edited and added to, in order to demonstrate a particular point of politics, ancestry and right to rule.

The keeping of registers of baptism, marriage and burial is essentially a post-Reformation phenomenon in Britain, and was neither universal nor complete. Alongside this, in England and Wales, there were Heralds' visitations by officers of the College of Arms from 1530 onwards and roughly every 30 years (a generation) thereafter until 1686. These were a way of documenting and checking claimed rights to coats of arms, but generated useful pedigrees and lineages on the way. Scotland had restarted its own Public Register of All Arms and Bearings in the 1670s, along with a Register of Pedigrees and Birthbriefs. However, in both countries, these were mainly for the titled, landed and/or rich (less so in Scotland), whereas a Parish Register might be expected to capture everyone.

It took statutory (and very soon after, compulsory) registration of vital events to give anything like a clear picture for the majority of the populus; these began in 1837 in England, 1855 in Scotland and the period 1846-1864 for Ireland. Added to these, the censuses allowed the governments a demographic and statistical picture-from 1801 these were purely summative, so as to give a snapshot each decade of population patterns, numbers of those engaged in agriculture or available for military service, for instance, and the exponential growth in population as the economy and agricultural production improved, as first shown by Malthus [7]. Censuses became genealogically useful—with names, ages, locations and additional details collected with increasing complexity from $1841^{5}$. The USA had a Federal Census each decade from 1790, but the first was essentially a head-of-household survey, and George Washington reportedly thought the final population size generated to be an underestimate.

Much of this is a sense for meaning, one thing the Present cannot give us, as the Now is frozen, like Zeno's arrow. Meaning comes from context and thus from history. This could be the Grand Sweep of events, or personal history (as explored by psychoanalysis, for example) or individual family history. How, why and when did this person go from Then and There to Here and Now? When and why did our ancestors choose (if they did choose) this or that craft, trade, profession, lifestyle, residence?

Some historians will refer to "Historical Forces"-migrations being among these-but this ignores and avoids the microscopic examination of individual motivations. Just as a solid object resolves, at high enough magnification, to individual particles held together by close-acting forces but consisting largely of empty vacuum, scrutiny of family history shows the separate motivations acting on individual people. Migrations, or participation in some historical event such as a rebellion,

Collected anecdotally and at classes over the past 20 years or so, and necessarily synthesised and simplified herein.

There is a literature of ancestral identity within various works on ancestral tourism, notably see [4-6].

There are pre-1841 census "fragments" which have survived from various parts of Britain and Ireland, and there are extent censuses from (for example) some parishes in Midlothian, Scotland, dated 1790, 1811, 1821 and 1831. 
may seem like mass movements, but the individual motivations may not have been identical in every case, with a different assessment of "push" and "pull" factors acting on each person or family grouping.

\section{Epistemology and Cognition}

None of this solves the conundrum at the heart of genealogy. Genealogy is in its essence epistemological. How do we know what we KNOW; and how do we KNOW what we know?

The answer to the first is apparently straightforward-we have evidence. But can all evidence be trusted (even official records)? And what if two sources contradict each other? Foucault explored this in a wider context as "insurrection of subjugated knowledges". But in this perspective, we have to accept that not all records, even official ones, are "correct". People tell lies to record-takers (altering or fabricating names, dates and places for a variety of reasons) and some are just errors introduced by inaccurate hearing, spelling, transcription etc.

The author's own great-great-grandfather is recorded in a number of different records-birth, marriage, death and two censuses - with four different surname spellings: Durrie, Derry, Dairy and Durie. In his death record, the informant-an elderly relative-spelled his name correctly, but confused his deceased wife with his mother.

It is a tenet of professional genealogy that any assertion should be accompanied, where possible, by multiple "proofs". These should be precise, and accurate. The two are not the same: if I told you my birthdate was 3 January 1955 at 10:05 a.m., that would be precise, but inaccurate; if I said I was born in 1954, that is accurate but hardly precise. What then, if an incorrect detail is given in a birth record - birthdate, or father's name perhaps — which get slavishly repeated in a death record, by an informant who has the original but no other surrounding information? This might be regarded as substantiation by multiple "proofs", coming from unrelated records. But they are related, as one reflects the other.

Nothing can really be "known". What genealogy shares with the natural sciences, but not the social sciences or humanities, is that it is not some struggle towards an ultimate "truth", but a process of diminishing deception. There is no "right", only less "wrong".

Much the same happens when someone's long-held family story is challenged by a genealogist. Some recent examples from client research, none invented because there is no need:

- $\quad$ Thesis: The Government put my ancestor off our land and took it.

- Antithesis: I can show that your ancestor was a spendthrift and wastrel, who had to sell his land to pay his debts.

- Thesis: Can you find out where we come from in England? I've visited, and just KNOW we're descended from a Lord or something; I can feel it in my soul.

- Antithesis: You're German, and your grandfather changed the spelling of his surname the better to fit in.

- Thesis: We were thrown out of our croft during the Highland Clearances.

- Antithesis: Here is evidence that your ancestors left long before the clearances, were not engaged in crofting, and were not from the Highlands.

Sometimes the subject is delighted by these revelations. Sometimes it is such a blow to the weltanschauung that it leads to cognitive dissonance, arising from the destruction of a long-held certainty which forms an aspect of self-identity, and the subject simply refuses to "believe" the genealogist, even when shown the relevant documents and records. Anecdotally, this is especially the case when the family's "origin story" is tied up with one or more narratives of victimhood ("We left because of religious persecution"; "We weren't welcome in New York, so we headed South and West in conditions of great privation", etc.).

By engaging with genealogy in a search for identity, the subject has his or identity challenged. This can, in the worst cases, lead to personality dissolution requiring counselling. One psychologist, treating such a patent, told me I had "no business telling her what she didn't want to hear". 
Then engage a fortune-teller, not a genealogist, I replied. (I fully accept that genealogists have a duty of care towards their clients, and I will not, for instance, put them in touch with long-lost children or parents, without the consent of all parties involved. The possibility of real damage is just too great.)

Then there is the cognitive issue: "how do we KNOW what we know?" There is a problem of definition here. We will not consider the mental act or process by which cognizance is formed, or its mental representation; that is the realm of perceptual psychology, although it was the original usage by Hobbes, Cudworth and others after "scholarly borrowing" from the Latin.

Nor do we consider here the Scots Law meaning: the process in the Court of Session by which cases concerning disputes were determined.

Cognition, in the genealogical context (where it is considered at all), confines itself to the acquisition or formation of an argument or concept. Knowledge may be considered "certain" when it comes from personal view or experience; but this can be flawed, as in suddenly discovering that a parent is not the biological parent, despite a lifetime of "knowing" that. Or, there is a rational and trackable process of argument by which a case is established: this is a "scientific" approach, in that the hypothesis can be challenged, and indeed overturned by new evidence (something which happens all the time to, for example, published genealogies).

\section{The Onomastic Issue}

Genealogy is greatly concerned with surnames, and it is widely accepted that surnames vary through time, geographically, and even within a single document. Beyond the spelling-error and hearing-error examples given above, genealogists have become rightly desensitised to surname spelling variants-despite what popular genealogy books and articles may say, McLevy and M'Levy are identical to and abbreviations of MacLevy. Nor is one Irish and one Scottish. Virtual wars are fought over whether MacDonald or Macdonald is the canonical form. The answer, of course, is that all variants are generally written down by the subject, but by some official, clerk, observer etc. and the subject neither has any opportunity to change it, or would care.

There is a Retour abstract where one individual is recorded as Durie, Durrie and Dury in a single paragraph. Indexers recognise this onomastic problem by cohering, for example, Rolland/Rowland and Moultrie/Moutrie/Mowtrie. And yet, there are genealogists who will avowedly research only MacEachern and not its variant McKechnie; who will not appreciate that there are separate origins of many families all called Currie, for example and many other surnames, particularly where locational, descriptive or occupational (Inglis, White, Smith); that despite appearances Dury and Drury are completely unrelated; and that not every name beginning with 'Du' and 'De' necessarily "came with William the Conqueror".

Surnames have variants, and it is up to a forensic examination and comparison of sources to demonstrate that the same or different subject or family is treated in conflicting records.

It is more perplexing where some seemingly objective piece of vital data varies between records-a date of birth, say, or the name or age of a parent, spouse or child. Sometimes it is just a mistake; sometimes a genuinely-held but demonstrably wrong belief; sometimes outright malfeasance. It is not unusual to find females who appear to age about seven years in each successive decennial census.

\section{Educational Approaches}

It was the consideration of all of the above that suggested a need for a coherent and high-level education and training programme in Genealogical Studies. There had long been short courses and one-off teaching events-some informal, some formalized at local Family History Society premises, and educational institutions, some even cohered into "certificates" at universities and similar organisations-but really nothing at a professional, postgraduate level at a university. It was 
also clear that praxis and methodological expertise was acquired haphazardly without a suitable professional training regime.

Against this background, the University of Strathclyde, Glasgow, Scotland, agreed to instigate such a programme. Sensibly, and in order to mitigate risk, this started in June 2005 as a Postgraduate Certificate (PgCert), taught on campus, part-time, on Saturdays across an academic year. It attracted 13 students. The next year, a Postgraduate Diploma (PgDip) was added, again on-Campus, and the PgCert was delivered online through a virtual learning system (VLE), absolutely in parallel with the campus course. The next year, campus classes were stopped and everything went online. A third year of MSc (Master of Science) ${ }^{6}$ by Dissertation was added. More recently, this three-year part-time programme has been complemented by a one-year, full-time version, also delivered online (first cohort 2016-2017) [8].

At roughly the same time, the University of Dundee, also in Scotland, was repurposing some of the elements of its Archives and other courses, and adding additional modules, to build to a Certificate-Diploma-MLitt pathway not substantially different from that of Strathclyde, although the subject emphasis differs [9]. At the time of writing, Strathclyde and Dundee are the only universities worldwide to offer Masters-level programmes of this type.

It would be remiss not to mention the Institute of Heraldic and Genealogical Studies in Canterbury, England, founded in 1961 as an independent educational charitable trust providing facilities for training and research in family history and related subjects. While not a university, its higher-level courses and qualifications have been formally equivalenced with those at Strathclyde (at least), and many educational and governmental bodies accept its qualifications as being of a similar level [10].

There are some undergraduate-level and lower Open Learning-type programs, in which genealogical studies need not form a significant portion. Brigham Young University (BYU) offers a bachelor's degree in family history as well as Bachelor of General Studies with a History/Family History Emphasis and a Minor in Family History/Genealogy [11]; BYU-Idaho offers an online applied associates degree (AAS) in Family History Research [12]; University of Limerick, Ireland, offers a Certificate in Continuing Professional Education (History of the Family \& Genealogical Methods) and in partnership with the Adult Continuing Education (ACE) at University College Cork (UCC), Ireland, there is a Diploma in Genealogy Studies [13]. The History of Family MA at the University of Limerick, Ireland, is more focused on sociological and historical issues of family, communities, migration and related subjects [14]. The University of Leicester, England, offers an MA in English Local History and Family History, in which Family History is only an optional Module [15].

\section{Commoditisation and Commercialization}

There could be a much discussion here of how genealogy has become a commodity-both in the sense that professional genealogists sell their services; and in the provision of paid-for databases, places to upload family trees and other commercial possibilities. It would be worth consideration of how far the commercial bodies' assertions that they merely provide "a finding aid" and take no responsibility for the validity of any data uploaded by user, is a service to then genealogical community or a dereliction of a duty of care.

Alongside this, there is the sterling work of the Church of Latter Day Saints and the Genealogical Society of Utah to make as many genealogical sources as possible free at the point of use. Many local and national societies have taken a similar approach. This is not strictly "commercial", but is no less a "commoditization", however laudatory

6 It is often questioned why this is not a Master of Arts (MA). Apart from a discussion about whether genealogy is a science or an art, it should be realised that at Scottish universities an MA is an undergraduate qualification while MSc is postgraduate. 


\section{Summary}

This article, perhaps befitting the introduction to a new journal, raises many issues possibly worthy of further scrutiny (if only to dismiss some of the assertions above). Rarely do many of these considerations enter into the consciousnesses of even the leaders in professional genealogy. (There are honourable exceptions-the pioneering work of Shown Mills into genealogical proof standards, for instance, but now over 50 years old.) [16]. This is both a reflection and an outcome of the dearth of scholarly scrutiny and interest to date.

It is to be hoped that future issues of Genealogy will explore some of these. Subjects worthy of future study and scholarly discussion might include: motivational studies; the choice of ancestral identity; the nature of "genealogical proof"; standards and ethics; becoming a qualified profession.

Genealogy may be a new beginning: fiat lux.

Conflicts of Interest: The author declares an interest, in having started, designed and directed (from 2005 to 2011) the Genealogical Studies courses at the University of Strathclyde, Glasgow, Scotland. He is now an Honorary Fellow there, but also teaches at other institutions. Recently, he was among those who established, for the first time, a Register of Qualified Genealogists.

\section{References}

1. Bernard Williams. Truth and Truthfulness: An Essay in Genealogy. Princeton: Princeton University Press, 2004.

2. Manfred Max-Neef. "Foundations of transdisciplinarity." Ecological Economics 53 (2005): 5-16. [CrossRef]

3. Basarab Nicolescu, ed. Transdisciplinarity—Theory and Practice. Cresskill: Hampton Press, 2008.

4. Duncan Sim. American Scots: The Scottish Diaspora and the USA. Edinburgh: Dunedin Academic Press, 2011.

5. Duncan Sim, and Murray Leith. "Diaspora tourists and the Scottish Homecoming 2009." Journal of Heritage Tourism 8 (2013): 259-74. [CrossRef]

6. Anthony Patterson. "Brand Ireland: Tourism and National Identity." Available online: https://www.researchgate.net/publication/251319582_Brand_Ireland_Tourism_and_National_Identity (accessed on 1 November 2016).

7. Thomas Robert Malthus. An Essay on the Principle of Population, 6th ed. 2 vols. London: John Murray, 1826.

8. University of Strathclyde Glasgow. "Genealogical, Palaeographic \& Heraldic Studies." Available online: http://www.strath.ac.uk/courses/postgraduatetaught/genealogicalpalaeographicheraldicstudies/ (accessed on 1 November 2016).

9. Centre for Archive and Information Studies. "Family and Local History." Available online: http://www.dundee.ac.uk/cais/programmes/familylocalhistory/ (accessed on 1 November 2016).

10. The Institute of Heraldic and Genealogical Studies. Available online: http:/ /www.ihgs.ac.uk (accessed on 1 November 2016).

11. Brigham Young University. Available online: http://familyhistory.byu.edu/ (accessed on 5 November 2016).

12. BYU-Idaho. "Future Students—Aas in Family History Research." Available online: http://www.byui.edu/ online/degrees-and-programs/family-history-research-aas (accessed on 5 November 2016).

13. Irish Ancestry Research Centre (IARC). Available online: http://irisharc.org/education/ (accessed on 15 November 2016).

14. University of Limerick. "Arts, Humanities \& Social Sciences: History of Family MA." Available online: http://www.ul.ie:8081/graduateschool/course/history-family-ma (accessed on 1 November 2016).

15. University of Leicester. "English Local History and Family History." Available online: https://le.ac.uk/ courses/english-local-history-and-family-history-ma (accessed on 5 January 2017).

16. Board for Certification of Genealogists. Genealogical Standards, 50th Anniversary Edition. Nashville and New York: Ancestry Imprint, Turner Publishing, 2014.

(C) 2017 by the author; licensee MDPI, Basel, Switzerland. This article is an open access article distributed under the terms and conditions of the Creative Commons Attribution (CC-BY) license (http://creativecommons.org/licenses/by/4.0/). 